Holding On 



\title{
Holding On
}

\author{
Family and Fatherbood during \\ Incarceration and Reentry
}

\section{Tasseli McKay, Megan Comfort, Christine Lindquist, and Anupa Bir}

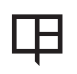


University of California Press, one of the most distinguished university presses in the United States, enriches lives around the world by advancing scholarship in the humanities, social sciences, and natural sciences. Its activities are supported by the UC Press Foundation and by philanthropic contributions from individuals and institutions. For more information, visit www.ucpress.edu.

University of California Press

Oakland, California

(C) 2019 by Research Triangle Institute, d/b/a/ RTI

International

Library of Congress Cataloging-in-Publication Data

Names: McKay, Tasseli, 1978- author. | Comfort, Megan, author. | Lindquist, Christine, author. | Bir, Anupa, author.

Title: Holding on : family and fatherhood during incarceration and reentry / Tasseli McKay, Megan Comfort, Christine Lindquist, and Anupa Bir.

Description: Oakland, California : University of California Press, [2019] | Includes bibliographical references and index.

Identifiers: LCCN 2018058270 (print) | LCCN 2019000208 (ebook) | ISBN 97805209733 I2 (ebook) | ISBN 9780520305243 (cloth : alk. paper) | ISBN 9780520305250 (pbk. : alk. paper)

Subjects: LCSH: Male prisoners-Family relationshipsUnited States. | Prisoners' families. | Fathers-Effect of imprisonment on.

Classification: LCC HV8886.u6 (ebook) | LCC HV8886.u6 M352019 (print) | DDC 362.82/950973-dc23

LC record available at https://lccn.loc.gov/2018058270

Manufactured in the United States of America

$\begin{array}{llllllllll}28 & 27 & 26 & 25 & 24 & 23 & 22 & 21 & 20 & \text { I9 }\end{array}$

I0 $\quad 9 \begin{array}{lllllllll} & 8 & 7 & 6 & 5 & 4 & 3 & 2 & \text { I }\end{array}$ 